This is a self-archived version of an original article. This version may differ from the original in pagination and typographic details.

Author(s): Lillie, Nathan; Simola, Anna

Title: The Crisis of Free Movement in the European Union

Year: 2016

Version:

Copyright: (c) FrancoAngeli, 2016.

Rights: In Copyright

Rights url: http://rightsstatements.org/page//nC/1.0/?language=en

Please cite the original version:

Lillie, N., \& Simola, A. (2016). The Crisis of Free Movement in the European Union. Mondi Migranti, 2016(3), 7-19. https://doi.org/10.3280/MM2016-003001 
The Crisis of Free Movement in the European Union

\author{
Nathan Lillie \\ nathan.a.lillie@jyu.fi \\ tel: 0408054633 \\ Anna Simola \\ anna.simola@helsinki.fi
}

The European Union is in crisis, and a major part of this is the increasing political backlash against the free mobility of persons. Probably the most dramatic symptom of this is Brexit, which could result in the stripping of rights or, in some scenarios, even physical expulsion of millions of people, whether Britons living in other EU countries, or EU citizens presently living in Britain. While the vote outcome apparently took policy makers by surprise, it represents a trend to redefine the status of intra-EU migrants in ways which clarify that EU citizenship is not equivalent to citizenship in the host country of residence. Unresolved contradictions between supernationally regulated free mobility and national sovereignty have come to the fore, precipitating political crisis. This is a serious obstacle for the European project, and one which is fundamentally embedded in the design of the European integration. As a social engineering project driven by "spill-over," European integration incentivizes elites to cooperate transnationally, but leaves large portions of national civil society outside this élite consensus. The consequence is that free movement of persons is stuck in a fragmented and variegated regulatory mode in which the social rights of mobile persons are precarious and dependent on market contingencies.

The European Union tends to treat society and economy as separate fields in terms of regulation with markets operating transnationally, while social issues remain national. The European Union has as a core raison d'être the breaking down of barriers to market governance, and these barriers are quite often important elements of national social regulation. As a result, EU institutions tend to treat the market as a fundamental organizing principle of society, which cannot be overturned through democratic politics. EU politics is remote to national concerns, opaque to those actors not obsessively involved in Brussels politicking, and difficult for citizens to influence (Follesdal and Hix 2006, 534-537). This configuration of interests pits national sovereign democracy against open borders - a conflict which is not irresolvable (Carens 2013), but also one which the EU institutions are not sufficiently robust to resolve. The EU is not a democratic polity with the legitimacy, authority and institutional infrastructure to reconcile diverse interests, manage the regulatory demands of free movement, and provide a veneer of legitimacy to the outcome. The principle that states control immigration has been overturned by stealth, so that the levers used by national governments to respond to popular pressures for immigration control are no longer available.

This article will first show that how the institutional construction and judicialization of the EU integration process have furthered the cause of free movement, but produced a backlash because of their automatic and mechanistic dynamics. Next, we argue that the backlash produced by free movement is mostly covert - i.e. as changes to national administrative practices which challenge free movement principles. The next section argues that challenging free movement is producing precarity through variegated 
access to citizenship rights, and this precarity undermines the very national welfare regimes variegate citizenship is intended to protect.

\section{The Institutional Construction of the European Union}

At the basis of the conflict is a formulation of EU citizenship rights which put the interests of mobile and immobile people in conflict. It is an outcome of the way in which European integration has been sold to Europe as an inevitable project, which will bring economic and cosmopolitan benefits to all. The inevitability of its free movement objectives, which progressively chip away at national systems, removes them from discussion, forcing those who would contemplate open restrictions on mobility into a binary choice of leaving the EU or not. On the other hand, it is also possible for national administrations to carry about de facto restrictions. Although such restrictions are highly contested, and only impact some mobile citizens in some EU member states, they represent a crumbling of the EU consensus around mobility. Furthermore, the possibility that social rights might be removed places mobile Europeans in precarious circumstances, unsure whether they will be able to draw social benefits when they move abroad to work. For EU citizens, their right to move and work is not geographically congruent with their social security, raising the possibility that 1) EU citizens will find themselves ineligible for social security after having some unfortunate life event when moving abroad to work and 2) mobile EU citizens will be more exploitable by employers because their lack of social security makes them cheaper and lowers their reservation wage. While such situations do sometimes arise out of neglect rather than deliberate policy, in the past the direction of EU regulation of free mobility has been to coordinate regulation so as to close social security gaps, moving towards ever closer parity of social rights access for mobile citizens. On the other hand, at present, national efforts to draw a sharper line differentiating between natives and other EU member state citizens in access to social rights threaten to create a two-tier system of social citizenship within the EU.

Free movement has always been an explicit goal of the European Union, and is indeed written into the European Economic Community's (EEC's) founding document, the 1957 Treaty of Rome. The EEC (later renamed the European Union), was originally a customs union with supranational governance elements to manage the process of economic integration. Economic integration would lead to political integration, which would guarantee peace for Europe. This goal was explicitly in the minds of Europe's original architects; as stated by Robert Schumann (1950): "Europe will not be made all at once, or according to a single plan. It will be built through concrete achievements which first create a de facto solidarity....The solidarity in production thus established will make it plain that any war between France and Germany becomes not merely unthinkable, but materially impossible." Thus, despite themselves, and without explicitly deciding to, national actors would gradually become so interdependent as to eliminate the national differences, interests and prejudices which allowed war to occur. To implement this idea came the framework, later much developed by European legislation and jurisprudence, for governing the 'four freedoms', of movement of goods, capital, services and establishment, and labour. Transnational labour mobility would be increased over time "by systematically and progressively abolishing those administrative procedures and practices... the maintenance of which would form an obstacle to liberalisation of the movement of workers (Treaty of Rome, Article 49)." 
The notion of furthering integration not through explicit decisions of high politics, but of arranging institutions in such a way as to reward a self-reinforcing virtuous circle of integration was analyzed in the classic book The Uniting of Europe (Haas 1958). Haas founded the influential neo-functionalist theory of integration on which many fundamental assumptions and expectations about the EU have been based- both in scholarship and policy. Notably, Haas advanced the idea of spill-over, that transnational integration in one policy area creates pressures for further integration in other areas. Despite the critiques leveled at it over the years, spill-over has stood the test of time as an explanation for why European integration often seems like a self-sustaining process (Rosamund 2005). Spill-over provides federalists with a flag of manifest destiny to justify policies which carry integration forward.

Because the European Union arose as out of a treaty between sovereign states its decision rules reflect concerns about sovereignty and the management of domestic political priorities. Council of Minister's decision-rules make it difficult to pass legislation which one or more of the large member nations find objectionable. In earlier times, there was need for unanimity, but there has been a trend toward ever smaller supermajority requirements. Still, when combined with the need for the Commission to initiate legislation and the Parliament to approve it, crafting responsive legislation can be difficult. Because of this, EU decision making is characterized by a 'joint decision trap,' favouring the status quo, and slowing the progress of policy harmonization (Scharpf 2006). Economic integration and spillover generate demands for political integration but often the EU cannot respond with legislation.

Instead, the Court of Justice of the European Union (CJEU) has stepped in, interpreting EU treaties and secondary legislation in order to ensure the practical observance of mobility rights. Court made law has tended to emphasis facilitation of mobility through mutual recognition of national standards, rather than harmonization of standards which it would be ill-equipped to manage, often drawing on directly on the treaties to justify basic EU principles. This has had the advantage of speeding EU integration along, and has served to guarantee rights of EU citizens when denied by national authorities. The CJEU has expanded its authority via the "doctrine of supremacy" of EU over national law, which over the decades has come to be accepted (Stone Sweet 2004). This has meant that CJEU case law has incrementally extended the entitlements of EU citizens abroad. It also has enhanced the normative and political weight of Union citizenship aspiring to make it central to the citizenship status of member state nationals (Kostakopulou 2012; Guild et al. 2015). In this way, the CJEU has pushed mobility rights forward through legal decisions, avoiding the need for a political consensus among European member state governments, let alone their citizens. There are strong utilitarian and normative arguments to do this; as Kostakopoulou (ibid.) argues, there is nothing fundamentally wrong in the CJEU testing the limits of EU citizenship given that its decisions have "enhanced the interests of ordinary citizens."

Yet, as a consequence of these processes, there are a set of social citizenship rights which have been granted to mobile EU citizens, which part of the Europeans feel are not deserved. The dispute around EU citizen's social rights is profoundly tangled in the disparity between the wealth and generosity of welfare systems of different EU member states. In Höpner and Schäfer's reasoning, free mobility severs the legitimizing 
connection between nationally distributed social benefits and the taxation paying for said benefits. They argue that this creates political and financial pressure for reducing welfare protections at national level (Höpner and Schäfer 2012, 431). This is not an inevitable outcome but is a consequence of the Court's mutual recognition line of response to spillover pressures; instead of reciprocal EU citizen rights emerging from contemporary public discussion and political decisions, they are inserted as fait accompli corollaries to treaties agreed by élites decades ago.

Although the pressures for integration arise spontaneously out of organic processes, the EU's response to them with regulatory solutions is bottlenecked by the EU's institutional design. The result is that citizens perceive the EU as responsible for migration, and for preventing national governments from taking action to limit it. For example, Italy has in recent years witnessed a severe decline in support for EU despite its long history of strong Euro-enthusiasm. Barbulescu and Beaudonnet relate this to growing concerns about the massive migration flows from both outside the EU, as well as from the Central and Eastern European member states, which the political elites in Italy have framed as European issues requiring European solutions (Barbulescu and Beaudonnet, 2014). While empirical research clearly indicates that overall, intra-EU migrants pay more into welfare systems than they receive (e.g. Dustmann and Frattini 2014), political attention tends to focus on the theoretical possibility of abuse, exceptional and egregious examples of abuse, or ill-informed notions that such abuse is widespread (Anderson 2015).

Public discussion of EU policies tends to be framed in terms of pro or anti- EU, rather than in terms of substantive debates about the policies themselves. Because the EU is put forward as an external constraint, opinions on EU policies become opinions on the desirability of the EU itself. Follesdal and Hix (ibid.) claim that in absence of real opportunities and spaces for formulation and contestation of EU's agenda and alterative policy choices, that is, because there is no visible 'opposition' on the EU level, that citizens cannot distinguish between opposition to the current EU policy and opposition against to the EU system. Hence, Eurosceptic and anti-EU parties have in many member states presented themselves as the opposition to the EU establishment as a whole (Follesdal and Hix 2006, 548-549). Eurosceptism has become increasingly mainstreamed and less contested across Europe, and anti-EU parties have also gained considerable footing in the European Parliament since the 2014 European elections (Brack and Startin 2015). Possibly responding to increasing anti-EU sentiment around the Union, the CJEU's most recent rulings have signaled a move closer to a legal framework under which the right to residency and right to equal treatment are more closely inter-linked, which opens for the member states a possibility to control EU citizens' access to their national welfare systems by applying residency conditions (Dougan 2016).

\section{The Support for Socially Sustainable Free Movement \& Reaction Against it}

A foundation stone of the EU since its beginning, free movement is simultaneously the EU's most popular and most unpopular achievement. Legally in EU member states, intra-EU mobile persons (particularly those entitled to the status worker) have an extensive set of rights to remain, to work, and to draw social benefits. Traditionally, the division line has been set between EU citizens and the so-called third country nationals. 
After the 2004 EU enlargement however, barriers were built between the 'new' and the 'old', with the new member state citizens temporarily and partially excluded from the right to free movement and equal treatment (Currie 2008, 3). Now, after the last 'transitional period' of temporary exclusion finally expired in January 2014, some member states appear unwilling to let go of direct movement restrictions and have found novel ways to continue to restrict the social rights of mobile EU citizens.

In the UK, for instance, the negative public discussion around intra-EU migration and policy of the UK Government reproducing 'the banal national lines of difference' problematized the realisation of European citizenship already in pre-Brexit years (Tonkiss 2013, 44; Anderson 2015). Indeed, the fight against free movement rights has been fought primarily on national terrain, framed as a problem of uncontrolled immigration, job competition and welfare scrounging.

Importantly, citizens of other EU states who are taking advantage of free movement rights are still often perceived as foreign migrants by natives in popular debates. For example, in their study on the UK press, Balbanova \& Balch (2010) find that press coverage frames intra-EU mobility in communitarian terms of 'us and 'them', with a dominate justificatory frame of 'managed migration,' in which migration is promoted on the basis of its economic benefits to host country citizens. Within the EU states have given up the right to autonomously regulate intra-EU migration, but there is still a popular expectation on national governments that migration is something which they can and should regulate at the national level, for the welfare of national citizens (Paul 2016,1640 ). Nation states remain the focal point of social and political life (Habermas 2012), and citizens expect and demand that their governments will regulate issues such as who is admitted to the national territory, who has access to rights of residence, who is allowed to accept employment, and who has the right to social benefits (Carens 2013). At the same time, member states policy choices in terms of social rights are increasingly subject to 'European scrutiny'. An inherent tension remains between the administrative power of the member states and the regulatory role of EU authorities aiming to ensure citizens' effective exercise of rights throughout EU territory (Maas 2013, 97-98).

The legitimacy of EU citizenship in the eyes of European people and the extent to which they support the principles of equal treatment and non-discrimination, are of course fundamental questions when the member states future approaches with regards to free movement are concerned. There is also still a widespread support for free mobility and the cosmopolitan project behind it (Eurobarometer 2015; Favell and Reimer 2014). The point here is not that most Europeans are knuckledragging nativists, but rather that there has been little or no space for rational discussion, to shift away from the 'us' and 'them' framing, which continues to bedevil the free movement project. Freedom of movement is often praised to be the best known and most valued EU citizenship right among the Europeans that "epitomizes the EU in the minds of Europeans" (Recchi 2015, 1). However, the extent to which EU citizenship actually contributes to their day-to-day experience and social status is strongly related to whether or not they are making use of their right to mobility (Ackers and Dwyer 2002, 3), something that a vast majority of EU nationals are not doing. Hence, for many questions related to EU citizenship remain rather abstract. 
Although the recent debate around free movement would suggest that the Europeans generally reject any expansion of EU migrants' rights, this is only one part of the picture. Indeed, the resistance is stronger in countries receiving major flows of intra-EU migrants, but even in these countries the population as a whole does not lack solidarity towards the other EU citizens and question the legitimacy of their rights (Gerhards et al., 2016). Nevertheless, the increase in migration flows that followed the EU enlargement and the subsequent economic crisis has aggravated the tension around EU migration in the more affluent EU countries with important consequences for their national politics. Apart from the open anti-EU-migration rhetoric mainstreamed in certain countries, others have more insidiously implemented policies directed at restricting the free movement in their own terrain. Since enlargement, several member states have made attempts to change their national legislation in a way that enables the exclusion of EU citizens (particularly non-active citizens and job seekers) from social assistance benefits, withdrawing their 'right to reside' if they make claims to entitlements (Minderhoud 2009). Perhaps one of the most striking example is Belgium, which has since 2010 established an systematic administrative practice enabling expulsions of EU citizens it considers, following the wording of the Directive 2004/38, are putting an 'unreasonable burden' on its social assistance system. Since 2012 it has removed the residence permits of around 2500 EU citizens per year (Barbulescu et al. $2015,37)$. Contrary to precedent cases of systematic European expulsions targeting principally ethnically discriminated minorities, namely the Roma population (Carrera 2014), this time in principle any EU citizen unable to demonstrate holding a paid work contract, 'a reasonable chance of finding employment' or 'sufficient resources' may receive an 'order to leave the territory'. The automatic and systematic features of this practice have quite obviously infringed EU law and it has met strong criticism from civil society as well as from the European Commission. This pressure however, has not made Belgium abandon its policy.

\section{Variegated EU citizenship and precarity}

EU citizens have access to a pan-EU labour market, but their social insurance access is still divided by national lines, variegating social citizenship of EU workers based on the EU and national categories of residency they happen to fall into. The result is to commodify those who fall outside the charmed circle of full benefits access. To the extent the right of free movement in the European Union is tied to paid employment, mobile EU citizens are in a precarious position. Although significant social rights are attached to the European citizenship in the context of interstate mobility, these rights are ultimately reserved to those who fall within the privileged status of 'worker'. For the rest, there is a whole 'microcosm of citizenship hierarchy' (Ackers and Dwyer 2002, 4) granting family members of the 'worker' full but derived rights and 'job seekers' only a limited access to social protection (Currie 2008). The so-called non-active citizen are required to demonstrate financial autonomy if they wish to claim right to free movement (Ackers and Dwyer ibid.). The definitions of these categories remain vague, leaving significant leeway for national interpretation and bureaucratic discretion.

Obviously, access to social benefits while in employment is important, but it immediately becomes much more important once one loses one's employment. Restricting the social rights of mobile EU citizens, while continuing to allow free movement for work, has to potential to undermine social rights by creating a precarious underclass with a lower reservation wage. In economics, the term "reservation wage" 
refers to the lowest wage a worker will accept for a particular job; a worker who is eligible for benefits will have a higher reservation wage than one whose only alternative is starvation. While European welfare systems differ in their inclusiveness and generosity, they all serve to partially de-commodify labour by insuring that the living standards of citizens are independent of pure market forces. Effective citizenship - the ability to fully participate in society - depends on access to these rights (Somers 2008). However, access to these social rights depends also on formal citizenship, and on the practical recognition of formal citizenship, thus bringing the causality in a circle.

Social citizenship have become dependent on market factors for immobile citizens as well; mobile status is but one contingency among many. Also immobile citizens who are unemployed or in precarious employment have their rights limited in various ways. In this way, the broader context of increasing precarity plays into this EU mobility debate, as European welfare states come under challenge, and "insider" groups attempt to preserve their rights relative to "outsiders", who may be migrants, temp workers, long term unemployed, young people or ethnic minorities. European integration has done little to change the European welfare state directly - at least not yet. European welfare states continue to differ significantly in how much decommodification they provide (Esping-Andersen 1990). Despite much discussion about the end of the welfare state, overall levels of welfare state spending in EU countries have decreased very little even after the onset of economic crisis, although this is very uneven - some countries have seen very substantial cuts, while others modest increases (OECD 2014). Coordinated attacks by European institutions on national welfare states are in progress, however, with cooperation from national politicians (Erne 2014), and there has been a marked turn to reshape welfare programs so that they are compatible with market norms, by, for example coercing unemployed to undertake very low paid employment (Greer 2015). Although welfare states are becoming workfare states, each is taking its own path to this end. The sharpening of precarity for non-mobile Europeans could, in open political discussion with the right framing, provide a basis of solidarity with mobile Europeans. Instead, competition for shrinking resources is deepening the divide.

Thus precarity is not merely a condition of the migrant, but has been a growing characteristic of western political economies generally, hence touching on the 'immobile' as well as the 'mobile' (Schierup et al. 2006; Sassen 2014) Precarity causes commodification, and is caused by it creating a vicious circle. In our investigation of mobile EU citizens, we assume this precarity to be associated with exclusion from the welfare system, and the conditioning of inclusion on the labour market position of the migrant.

The irony is that while populist intentions may be to preserve access to social rights for native immobile workers by creating dualized "insider/outsider" social rights access, the creation of a mobile underclass is likely to do just the opposite. Workers who do not have social rights access are desperate for work and therefore cheaper. As a result, they take over labour markets where they are present, and undermine conditions for native workers.

\section{Is Free Mobility Incompatible Principle with Nationally Bounded Welfare States?}

The crux of the problem relates to the EU's treatment of economic policy as separate from social policy. Markets, however, are inextricably embedded in society, and extension of market governance produces societal effects, and societal reactions (Polanyi 1944). We have argued that the situation predicted by Höpner and Schäfer 
(2012) - that the EU's regulation of mobility via mandates allowing mobile European access to social rights would undermine support for mobility - has come to pass, although not precisely in the way they predicted. Instead of the dismantling of national welfare states, the pressures of integration are resulting in the surreptitious and less surreptitious undermining of national recognition of EU social citizenship rights.

Immobility remains the norm, so that popular conceptions tend to continue to see states as membership bodies, who are sovereign in their choice of whom to admit to the territory, and when to grant newcomers access to privileges and benefits. This way of thinking normalizes immobility and turns mobile citizens into supplicants, who may be admitted, but only if their presence benefits those already there. Because the EU we live in involves large numbers of people moving all the time, limiting their citizenship access means creating a vast underclass. Variegated citizenship has developed, with people able to move from place to place to work, but having differential access to the social rights depending on the value of their labour on the market, and on their relationship to the territory they are in. They compete with immobile native workers, but not on fair terms - their lack of rights makes them cheaper and more desperate, so they accept less. The impulse to respond to increased mobility with greater limits and restrictions on social citizenship rights, worsens the problem rather than solving it, because it recommodifies the labour of those who for one reason or another are caught outside the charmed circle of social citizenship.

Bibliography

Ackers, Louise \& Dwyer, Peter (2002) Senior Citizenship? Retirement, migration and welfare in the European Union. Bristol: Polity Press.

Anderson, Bridget (2015) "Immigration and the Worker Citizen". In the book Bridget Anderson and Vanessa Hughes (eds.) Citizenship and Its Others. Basingstoke \& New York: Palgrave, 41-57.

Balabanova, Ekaterina, Alex Balch (2015) "Sending and receiving: The ethical framing of intra-EU migration in the European press," European Journal of Communication, 25(4) 382-397

Barbulescu, Roxana, Lafleur, Jean-Michel and Stanek, Mikolaj (2015) Western Europe 2016. Europa Publications (ed.) Routledge.

Barbulescu R \& Beaudonnet L (2014) Protecting Us, Protecting Europe? "Public Concern about Immigration and Declining Support for European Integration in Italy." Perspectives on European Politics and Society, 15(2), 216-237

Bauböck, Rainer (2011) "Temporary migrants, partial citizenship and hypermigration," Critical Review of International Social and Political Philosophy, vol. 14, no. 5: 665-693.

Brack, Nathalie and Startin, Nicholas (2015) Introduction: Euroscepticism, from the margins to the mainstream. International Political Science 36(3), 239-249.

Carens, Joseph (2013) The Ethics of Immigration. Oxford: Oxford University Press. 
Caro, Erka, Lisa Berntsen, Nathan Lillie, Ines Wagner (2015) "Posted Migration and Segregation in the European Construction Sector" Journal of Ethnic and Migration Studies, 41 (10), 1600-1620.

Carrera, Sergio (2014) "The Framing of the Roma as Abnormal EU Citizens: Assessing European Politics on Roma Evictions and Expulsions in France". In the book E. Guild et al. (eds.) The Reconceptualization of European Union Citizenship. Leiden \& Boston: Brill, 33-63.

Currie, Samantha (2008) Migration, Work and Citizenship in the Enlarged European Union. Aldershot: Ashgate.

Dølvik Jon Erik and Visser Jelle (2010) Free movement, equal treatment and workers' rights: can the European Union solve its trilemma of fundamental principles? Industrial Relations Journal 40(6): 491-509.

Dougan, M. (2016) National Welfare Systems, Residency Requirements and EU Law: Some Brief Comments. European Journal of Social Security, 18(2), 101-105

Dustmann, Christian and Frattini, Tommaso (2014) "The Fiscal Effects of Immigration to the UK'. Economic Journal 124 (580): 593-643.

Ellerman, David (2005) "Translatio Versus Consessio: Retrieving the Debate About Contracts of Alienation with an Application to Today's Employment Contract”. 33 POL. \& SOC'Y 449.

Eurobarometer (2015) Standard Eurobarometer 83, Public Oppinion in the EU. Available at: http://ec.europa.eu/public_opinion/archives/eb/eb83/eb83_publ_en.pdf

Favell, Adrian and Reimer, David (2014) Winners and Losers? Citizens and Sceptics? European Integration and the Spread of Cosmopolitanism. EUCROSS Policy Brief, 1-11.

Ferrera, Maurizio (2009) "The JCMS Annual Lecture: National Welfare States and European Integration: In Search of a 'Virtuous Nesting'”. Journal of Common Market Studies, 47(2), 219-233.

Gerhards, Jürgen, Lengfeld, Holger, Häuberer, Julia (2016) “Do European citizens support the idea of a European welfare state? Evidence from a comparative survey conducted in three EU member states". International Sociology 2016.

Guild, Elspeth, Kostakopoulou, Dora, Rotaeche, Cristina Gortázar (eds.) (2015) The Reconceptualization of European Union Citizenship. Leiden \& Boston: Brill, 33-63.

Haas, Ernst (1958) The Uniting of Europe. Berkeley, Stanford University Press.

Habermas, Jürgen (2012) The Crises of the European Union: A Response, Cambridge: Polity Press. 
Hansen, Peo and Hager, Sandy (2012) The Politics of European Union Citizenship. Deepening Contradictions in Social Rights and Migration Policy. New York \& Oxford: Berghahn Books.

Höpner, Martin and Schäfer, Armin (2012) 'Embeddedness in Regional Integration: Waiting for Polayni in a Hayekian Setting'. International Organisation, 66(3), 429-55.

Kostakopoulou, Dora (2012) “The European Court of Justice, Member State Autonomy and European Union Citizenship; Conjunctions and Disjunctions", in B. de Witte and Hans-W. Micklitz (eds.) The European Court of Justice and the Autonomy of the Member States. Leiden: Intersentia, 175-203.

Kostakopoulou, Dora (2014) "European Union citizenship rights and duties. Civil, political and social.” E. F. Isin \& P. Nyers (eds.) Routledge Handbook of Global Citizenship Studies. Oxon \& New York: Routledge, 427-436.

Lillie, Nathan (2016) "The Right Not to Have Rights: Posted Worker Acquiescence and the European Union Labor Rights Framework", Theoretical Inquiries In Law, 17, 40.

Maas, Willem (2013) "Free Movement and Discrimination: Evidence from Europe, the United States, and Canada". European Journal of Migration and Law 15, 91-110.

Minderhound, Paul (2009) Access to Social Assitance Benefits and the Directive 2004/38. In the book K. Groenendijk et al. (eds.) Illiberal Liberal States : Immigration, Citizenship and Integration in the EU. Farnham \& Burlington: Ashgate.

Nail, Thomas (2015) The figure of the migrant, Stanford: Stanford University Press.

Ong Aihwa (2006) Neoliberalism as Exception: Mutations in Citizenship and Sovereignty. Durham: Duke University Press.

Paul, Regine (2016) Negotiating varieties of capitalism? Crisis and change in contemporary British and German labour migration policies, Journal of Ethnic and Migration Studies, 42:10, 1631-1650.

Polanyi, Karl (1944) The Great Transformation

Pouza, Thomas (2016) "EU posted worker reform is blow to single market", EU Observer, https://euobserver.com/opinion/132609

Recchi, Ettore (2015) Mobile Europe. The theory and practice of Free Movement in the EU. Houndmills \& New York: Palgrave.

Rosamund, Ben (2005) "The uniting of Europe and the foundation of EU studies: Revisiting the neofunctionalism of Ernst B. Haas" Journal of European Public Policy 12(2): 237-254.

Sassen, Saskia (2014). Expulsions: brutality and complexity in the global economy. Massachusetts \& London; Harvard University Press. 
Scharpf, Fritz (2006) “The Joint Decision Trap Revisited”, Journal of Common Market Studies 44(4): 845-865.

Schierup, Carl-Ulrik, Hansen, Peo \& Castels, Stephen (2006) Migration, Citizenship, and the European Welfare State. A European Dilemma. Oxford \& New York: Oxford University Press.

Schumman, Robert, "The Schuman Declaration - 9 May 1950" https://europa.eu/european-union/about-eu/symbols/europe-day/schumandeclaration_en

Somers, Margaret (2006) Citizenship, Statelessness and Market Fundamentalism: Arendtian Right to have Rights. In M. Bodemann \& G. Yurdakul (eds.) Migration, Citizenship, Ethnos. London: Palgrave Macmillan

Soysal, Yasemin (2012) "Citizenship, immigration, and the European social project: rights and obligations of individuality". The British Journal of Sociology, 63(1), 1-21.

Stone Sweet, Alec (2004) The Judicial Construction of Europe. Oxford: Oxford University Press.

Tonkiss, Katherine E. (2013) Post-national citizenship without port-national identity? A case-study of UK immigration policy and intra-EU migration. Journal of Global Ethics 9:1, $35-48$.

Van Apeldoorn, Bastian (2009) “'"The Contradictions of 'Embedded Neoliberalism' and Europe's Multi-level Legitimacy Crisis: The European Project and its Limits." In B. van Apeldoorn et al. (eds.) Contradictions and Limits of Neoliberal European Governance, 21-43.

Wagner, Ines (2015) “The Political Economy of Borders in a 'Borderless' European Labour Market," Journal of Common Market Studies, 53(6): 1370-1385. 